\title{
Nanosilver-decorated nanographene and their adsorption performance in waste water treatment
}

\author{
M. Jannathul Firdhouse and P. Lalitha*
}

\begin{abstract}
Background: Water, a precious resource for all living organisms has become a diminishing source in the present world. Reuse of water is a way of combating the scarcity of water. The remedy for the polluted water through ecofriendly approaches is a major challenging task for the researchers. Nanotechnology is expected to provide a better solution than the existing methods. Graphene, a novel carbonaceous material widely used in the field of nanotechnology is a promising substance in the treatment of polluted water.

Results: The present work deals with the bio-reduction of graphene oxide using the aqueous extract of Amaranthus polygonoides. The synthesized graphene was embedded with silver nanoparticles and Moringa oleifera pulverized seed powder. This modified graphene was used as adsorbent for simulated textile, tannery and paper mill effluents. The adsorption efficacy of graphene and modified graphene was compared with that of a commonly available adsorbent activated charcoal by analysing the water quality parameters before and after treatment.

Conclusions: The results revealed that the graphene loaded with the silver nanoparticles and M. oleifera seed powder possessed excellent adsorbent properties and showed good efficacy on reusability compared to conventional activated charcoal.
\end{abstract}

Keywords: Water, Graphene, Silver Nanoparticles, TEM, Adsorbent, XPS

\section{Background}

Water is one of the life-sustaining natural resources of billions of people and plays an important role in agriculture, ecosystem and health impacts around the world. From 2002 to 2008 the ground water of 109 billion cubic metres has diminished in the Indian states of Punjab, Rajasthan and Haryana (Rodell et al. 2009). The surface water systems are also threatened directly by the anthropogenic contaminants produced by various industries. This scenario has put the part of the world under the history of shortage of water, which serve sculpt for the water pollution. Developed nations have invested more in water technology, but the developing and undeveloped nations are at risk (Vorosmarty et al. 2010). Central and

\footnotetext{
*Correspondence: goldenlalitha@gmail.com

Department of Chemistry, Avinashilingam Institute for Home Science and Higher Education for Women University, Coimbatore, Tamil Nadu 641043, India
}

Northeast Asian countries experience more industrial pollution levels as indicated by BOD values than Southeast Asian countries (Evans et al. 2012).

Water gets polluted by waste water produced by various industries like textile, dyeing, paper, distillery, dairy, oil and refineries. The anthropogenic contaminants from the aforesaid industries can be classified as effluent discharge, solid wastes and other hazardous wastes (Lokhande et al. 2011). In India, most of the industries functions under the guidelines of the Central Pollution Control Board (CPCB) but, still the environmental circumstances are unacceptable (Rajaram and Das 2008; Khurshid et al. 1998; Pachpande and Ingle 2004; Prabha and Selvapathy 1997; Singare et al. 2010). In 1999 more than 50,000 people lost their lives due to the consumption of polluted water (Nevondo and Cloete 1999). Even after progressive technological development, WHO reports in 2005 reveal 4 billion cases of diarrhoeal 
diseases causing death up to 1.5 million children due to polluted water (WHO 2004).

The Ministry of Environment and Forests, Government of India marks textile industries under the category of the most polluting industries (Singh et al. 2005; Vinodkumar et al. 2012). It generates enormous amount of waste water through different processes like sizing, bleaching, mercerizing, dyeing and printing (Sharma et al. 2013). Textile effluents are characterized by high $\mathrm{pH}, \mathrm{BOD}, \mathrm{COD}$, chloride, suspended solids, heavy metals $(\mathrm{Cd}, \mathrm{Cr}, \mathrm{Cu}, \mathrm{Hg}$, $\mathrm{Ni}, \mathrm{Pb}, \mathrm{Zn}$, etc.), dyes, organic, inorganic compounds, etc. that gradually contribute to environmental demolition (Egborge 1991; Emongor et al. 2005; Federal Environmental Protection Agency [FEPA] 1991). Research for more reliable and cheaper methods to purify the polluted water at an affordable cost is thus on an increase.

Popular methods for the treatment of polluted water include physical methods (screening, comminution, flow equalization, sedimentation, filtration), chemical methods (chemical precipitation, adsorption, disinfection, dechlorination) and biological methods (trickling filters, activated sludge process, anaerobic digestion, aerated lagoon, rotating biological contactors, pond stabilization, biological nutrient removal, etc.) (Gupta 2011; Singh et al. 2011). The aforesaid methods are tedious, expensive and most of the time involves complex processes. Several studies on the treatment of effluent using microorganisms are also reported. Bacillus endophyticus VITABR13, a strain isolated from textile effluent decolourises azo dye (Prasad and Rao 2011). Selvam et al. 2012 examined the removal of colour by Trametes versicolor using dye industry effluent. The dyes present in the textile effluent are reported to be decolourised by white-rot fungi (Selvam and Priya 2012).

Low-cost activated carbon adsorbent prepared by biological means such as waste biomass sources (Moyo and Chikazaza 2013; Sugumaran et al. 2012; Alam et al. 2007), coconut shells (Cobb et al. 2012), Mimusops elengi (Renugadevi et al. 2011), cotton stalk (Lia et al. 2011), soya bean (Murayama et al. 2010), coconut husk (Ramakrishnan and Namasivayam 2009), Tamarind wood (Acharya et al. 2009), asphalt, heavy oil fly ash and coal fly ash (Uddin et al. 2007), cattle manure compost (Qian et al. 2007), chicken manure (Koutcheiko et al. 2007), Euphorbia rigida (Gerçel et al. 2007), coirpith (Ash et al. 2006), peanut, pecan and walnut shells (Ahmedna et al. 2004), Parthenium waste (Kadirvelu et al. 2002) and bagasse fly ash (Kumar et al. 2008) have been reported to treat industrial effluents. Treatment plants (reverse osmosis) are established to reuse the treated effluent and to obtain zero liquid discharge (Rajamanickam and Nagan 2010). Carbonaceous materials like activated carbon have proved to be an effective sorbent for the removal of metal ions, their complexes and other chemical species.
In 2010, the Madras High Court declared the Noyyal river unfit for human consumption as per the reports of National Environmental Engineering Research Institute (NEERI). In India, one-fifth of the exports are from the textile industries in Coimbatore and Tirupur areas. The untreated sewage and industrial effluents containing bleaching liquids, soda ash, sulphuric acid, hydrochloric acid, sodium peroxide, chemicals and various dyes are drain into the Noyyal River (The Hindu, 16th January 2012). Recently, Water Resource Organisation (WRO) of the Public Works Department laboured to rejuvenate the Noyyal system at Rs. 180 crores aided by World Bank in 2013 (The Hindu, 15th August 2013). All these necessitate the treatment of industrial effluents.

Nanographene, a newfangled carbon material has received significant attention in recent years, due to its excellent properties like high current density, good electrical conductivity, ballistic transport, large theoretical specific surface area, super hydrophobicity at the nanometre scale, chemical inertness, optical transmittance, high thermal conductivity, etc. (Firdhouse and Lalitha 2013, 2014). Carbon derived from biomass is considered to be environmentally friendly and widely used on a large scale (Wu and Zhang 2012; Huang et al. 2011; Sindhu et al. 2012). The carbonaceous materials were fused with several metal ions under high temperature treatment to achieve special chemical and physical properties for use as adsorbents in water treatment (Asasian et al. 2012; Nagashanmugam and Srinivasan 2011). High porosity and very high surface areas were obtained by preparing such carbonaceous materials in high temperature environment which can enhance adsorption capacity (Zouboulis and Matis 1997; Zaini et al. 2010).

The potential advantages of graphite over the reverse osmosis membranes are thicker (single to few layers), requires low pressure, water transport will be faster due to its high mechanical strength and large surface area. Cohen-Tanugi and Grossman (2012) reported that the nanoporous graphene membranes possess the ability to reject salt ions at higher permeabilities than the existing $\mathrm{RO}$ membranes. The removal of $\mathrm{Ni}$ (II) ions was achieved using graphene nanosheets $/ \delta-\mathrm{MnO}_{2}$ composite by Varma et al. 2013. Graphene oxide nanoplatelets fabricated onto membrane bioreactor suppressed the fouling produced by waste water, fivefold times better than the chemical cleaning agents (Lee et al. 2013). Anatase coupled with graphene removes the contaminants present in wastewater (Aglietto 2010). $\mathrm{AlO}(\mathrm{OH})$-chitosan composite loaded with silver nanoparticles are used in the development of water purifier at an affordable cost of US\$2.5/year per family (Sankar et al. 2013).

Moringa oleifera seeds have served as effective primary coagulants in water treatment by rural communities 
over the years (Dalen et al. 2009). The rural communities in India, Sudan, Malawi, Myanmar and Indonesia used the dried, powdered seeds of $M$. oleifera as a lowcost coagulant for reducing bacterial and viral contamination and also to remove turbidity from drinking water (Roloff et al. 2009). These seeds contain proteins which possess active coagulation properties (Olayemi and Alabi 1994; Sotheeswaran et al. 2011). The presence of benzyl isothiocyanate and benzyl glucosinolate in the seeds acts as prominent antibiotics and provides effective antimicrobial activity (Eilert et al. 1981). The seed protein is a natural polypeptide which helps in the sedimentation process and found to be non-toxic (Madsen et al. 1987). The polyelectrolyte $(1 \%)$ present in the seed possesses the capability to neutralize the formed charged colloid (Sapana et al. 2012).

In our present work, we have bio-reduced graphene oxide using the aqueous extract of $A$. polygonoides and characterized the graphene by UV-Visible spectroscopy, XRD, FTIR, Zeta potential and TEM analysis. Subsequently graphene was further sonicated $(3 \mathrm{~g} / 20 \mathrm{ml}$ ethanol) for $60 \mathrm{~min}$ and dried at $120{ }^{\circ} \mathrm{C}$ for obtaining few-layer graphene and to remove the unreacted ones. Thus the prepared graphene was used as adsorbent for the treatment of polluted water and different water quality parameters were analysed after treatment with the adsorbents. To enhance the antimicrobial activity of the synthesized graphene, graphene was decorated with silver nanoparticles. The non-toxic, anticoagulant properties of M. oleifera seeds and traditional knowledge of its uses as natural absorbent and eco-friendly antimicrobial agent for the purification of drinking water, prompted us to incorporate the seed powder for enhancing the properties of the prepared adsorbents. Hence graphene decorated with silver nanoparticles was further loaded with powdered M. oleifera.

\section{Methods}

Graphite powder and Silver nitrate were purchased from SD fine chemicals, India. A. polygonoides was collected from a vegetable vendor in Coimbatore. The analytical grade chemicals used in this work (calcium sulphate, magnesium sulphate, calcium chloride, magnesium chloride, 1,5-diphenylcarbazide, sulphuric acid, Rhodamine dye, Eriochrome black dye, Crystal violet dye, potassium dichromate, cellulose, phenol, Folin-Ciocalteu's phenol reagent and reducing sugar) were purchased from Merck chemicals, India.

\section{Preparation of plant extracts}

Fresh plant of Amaranthus polygonoides (20 g) was washed, blended and stirred continuously for $30 \mathrm{~min}$ at
$50{ }^{\circ} \mathrm{C}$. The mixture was filtered using Whatman filter paper and refrigerated at $-4{ }^{\circ} \mathrm{C}$.

\section{Preparation of graphene oxide}

Graphene oxide was prepared by modified Hummer's method (Ma et al. 2013; Ankamwar and Surti 2012). Graphite powder (2 g) was treated with concentrated sulphuric acid $(46 \mathrm{~mL})$ in ice-cold condition and stirred for $2 \mathrm{~h}$. Potassium permanganate $(6 \mathrm{~g})$ was added in regular intervals of $30 \mathrm{~min}$ at $35^{\circ} \mathrm{C}$ and the mixture was stirred continuously in an oil bath for $2 \mathrm{~h}$ at $50{ }^{\circ} \mathrm{C}$. Doubly distilled water $(92 \mathrm{~mL})$ was added with vigorous stirring for 15 min till dark brown suspension was obtained. Hydrogen peroxide $30 \%(280 \mathrm{~mL})$ was added until the solution turned pale yellow. The solution was filtered with $10 \%$ hydrochloric acid and finally with double-distilled water to obtain pure graphene oxide. Thus, the obtained graphene oxide was homogenized using an Ultrasonic homogenizer and dried in a vacuum.

\section{Phytoextract-mediated synthesis of graphene}

Stable graphene oxide was prepared by sonicating $60 \mathrm{mg}$ of graphene oxide in $120 \mathrm{ml}$ distilled water for $30 \mathrm{~min}$. The aqueous extract of $A$. polygonoides (SK) $(10 \mathrm{ml})$ was added to the stable graphene oxide solution and refluxed until the brown colour solution changes to black. The black solution was filtered using Whatman filter paper and dried.

\section{Characterization}

UV-visible spectrum and FTIR of nanoparticles were recorded using Double Beam Spectrophotometer-2202 (Systronics) and FTIR 8400S (Shimadzu), respectively. X'Pert Pro system with $\mathrm{Cu} \mathrm{K} \alpha$ radiation $(\lambda=1.54060 \mathrm{~A})$ operated at $45 \mathrm{kV}$ and $30 \mathrm{~mA}$ over the range of $2 \theta=10-70^{\circ}$ at a scanning rate of $2 /$ min was used for X-ray Diffraction (XRD) studies. Mass of graphene was recorded as a function of temperature in a SII-6300-TG-DTA (Exstar) Thermo gravimetric analyser under nitrogen flow. The zeta potential was analysed using NanoPartica SZ-100 series (Horiba) and maintained at a temperature of $25^{\circ} \mathrm{C}$ for $2 \mathrm{~min}$. The morphology of nanographene was examined using FEI's Tecnai ${ }^{\mathrm{TM}}$ $\mathrm{G}^{2}$ Transmission Electron Microscope. Raman spectrum was obtained using R-3000 QE with an excitation wavelength of $785 \mathrm{~nm}$ and optical resolution of $6 \mathrm{~cm}^{-1}$. Scanning Electron Microscope (e-SEM, FEI Quanta 250) was used to examine the morphology of the reduced graphene oxide (SKRGO) coated on the carbon substrate. The spectra were recorded using MULTILAB 2000 Base system (Thermo Scientific) with X-ray, Auger and ISS attachments. 


\section{Preparation of synthetic effluents}

Industrial effluents have a hodgepodge of organic and inorganic molecules. The primary aim of this research is to establish the efficacy of synthesized graphene in water treatment. The numerous ions and compounds in industrial effluents may interfere with the estimation procedures and hence it felt pertinent to prepare synthetic effluents.

Synthetic effluents were prepared in the lab as per literature given below in order to avoid interference of ions present in the industrial effluents and also in the estimation procedure. Three synthetic effluents namely textile effluent, tannery effluent and paper mill effluent were prepared as per literature data. Synthetic textile effluent was prepared by adding calcium sulphate $(130 \mathrm{mg} / \mathrm{L})$, calcium chloride $(312 \mathrm{mg} / \mathrm{L})$, sodium bicarbonate $(520 \mathrm{mg} / \mathrm{L})$, magnesium sulphate $(316 \mathrm{mg} / \mathrm{L})$, crystal violet solution $(5 \mathrm{~mL})$ and Rhodamine dye $(1 \mathrm{mg} / \mathrm{L})$ (Ranganathan et al. 2006; Ramesh Babu et al. 2007). The tannery effluent was prepared by adding sodium carbonate $(300 \mathrm{mg} / \mathrm{L})$, calcium carbonate $(300 \mathrm{mg} / \mathrm{L})$, sodium bicarbonate $(300 \mathrm{mg} / \mathrm{L})$ and chromium $(250 \mathrm{mg} / \mathrm{L})$ (Mahimairaja et al. 2011; Jain et al. 2006; Sivakumar et al. 2010). Paper mill effluent was simulated with the composition: calcium sulphate $(130 \mathrm{mg} / \mathrm{L})$, cellulose $(628 \mathrm{mg} / \mathrm{L})$, glucose $(186 \mathrm{mg} / \mathrm{L})$, calcium chloride $(312 \mathrm{mg} / \mathrm{L})$, sodium bicarbonate $(480 \mathrm{mg} / \mathrm{L})$, magnesium sulphate $(72 \mathrm{mg} / \mathrm{L})$ and phenol (40 mg/L) (Suriyanarayanan et al. 2010).

\section{Preparation of the adsorbents}

Five adsorbents were used in the study viz. (i) few-layer graphene (G) (ii) graphene decorated with silver nanoparticles (GA) (iii) commercially available activated charcoal (AC), graphene with $M$. oleifera seeds powder (GM) and (iv) graphene loaded with silver nanoparticles and powdered M. oleifera seeds (GAM). The adsorbent GA was prepared by sonicating the biosynthesized few-layer graphene (SKRGO) and graphene with silver nanoparticles (SK-AgNPs). The adsorbent GAM was prepared by mixing GA (150 mg) with the fine powder of M. oleifera seeds $(150 \mathrm{mg})$. Similarly for GM adsorbent but instead of GA, graphene (G) was incorporated. The slurry of five adsorbents (each $300 \mathrm{mg}$ ) was prepared by mixing fewlayer graphene $(G)$, graphene fabricated with silver nanoparticles (GA), activated carbon (AC) with $100 \mathrm{mg}$ of silica gel.

\section{Adsorption experiments}

Glass columns of height $30 \mathrm{~cm}$ and internal diameter $1.5 \mathrm{~cm}$ was set identically with four adsorbents. The effluent feed to the column was fixed as $10 \mathrm{ml}$ and the flow rate was maintained at $10 \mathrm{ml} / 15 \mathrm{~min}$. A total quantity of about $100 \mathrm{ml}$ of each effluent was treated with the four adsorbents. The reusability of the adsorbents was analysed using the same fixed bed column for the three different industrial effluents after continuous washing with deionized water and thermal activation at $70-80{ }^{\circ} \mathrm{C}$ for $6 \mathrm{~h}$. The water quality parameters before and after flow through the glass columns were estimated to analyse the potency of the adsorbents. The percentage of adsorption was calculated using the formula.

$$
\% \text { Adsorption }=\mathrm{C}_{\mathrm{o}}-\mathrm{C}_{\mathrm{e}} / \mathrm{C}_{\mathrm{o}} \times 100
$$

\section{Physicochemical characteristics to assess water quality}

The physicochemical characteristics of effluents and the water obtained after treatment with the adsorbents were determined using standard methods of APHA (2002). The water quality of effluents before and after treatment was tested by various parameters like colour, odour, $\mathrm{pH}$, conductivity $(20 \mathrm{mS})$ (conductivity metre), absorbance $(540 \mathrm{~nm})$ and transmittance (\%) (Photocolorimeter).

\section{Estimation of hardness-EDTA titration method}

The total hardness $(\mathrm{mg} / \mathrm{mL})$ of the three effluents before and after the treatment was estimated by EDTA titration method according to standard method.

\section{Estimation of chromium-Colorimetric method}

Chromium was determined by the colorimetric method by diphenylcarbazide method (Adeel et al. 2012). Ten millilitre of the tannery effluent sample before and after treatment ( $\mathrm{pH}$ between 7.5-8.0) was mixed with $1 \mathrm{~mL}$ 1,5-diphenylcarbazide solution and $1 \mathrm{~mL}$ sulphuric acid solution and diluted up to $50 \mathrm{~mL}$ with distilled water. After $15 \mathrm{~min}$, spectrophotometer readings were taken at $540 \mathrm{~nm}$ wavelengths against potassium chromate as standard.

\section{Estimation of phenol-Colorimetric method}

Total phenolic content (TP) was measured in triplicate using the Folin-Ciocalteu's phenol reagent, involving the addition of $200 \mu \mathrm{L}$ Folin-Ciocalteu's phenol reagent to $3.6 \mathrm{~mL}$ diluted sample. After $3 \mathrm{~min}, 800 \mu \mathrm{L}$ of sodium carbonate $(200 \mathrm{~g} / \mathrm{L})$ was added. The mixture was kept for $5 \mathrm{~min}$. The Prussian blue colour developed on the addition of Folin-Ciocalteu reagent to the samples. The solution was diluted with $20 \mathrm{~mL}$ of deionised water. The absorbance was measured at $540 \mathrm{~nm}$ using photocolorimeter by the procedure of Catalano et al. (1999) and Singleton et al. (1999).

\section{Determination of chromophoric groups-UV-Visible spectroscopy}

The untreated and treated effluents were analysed using UV-Visible spectroscopy to determine the intensity of the chromophoric groups in the samples. 


\section{Water quality testing in certified institution}

The physicochemical characteristics of textile effluent and the water obtained after treatment with the adsorbents were submitted to SITRA (South Indian Textiles Research Association) laboratory, service for the excellence certified institution for further certification of water quality parameters.

\section{Results and Discussion}

Graphene oxide bio-reduction with aqueous extract of A. polygonoides produced a visible colour change of the reaction mixture from brown to black after $7 \mathrm{~h}$ refluxing. The black colour solution revealed the removal of oxygen bonds and restoration of electronic conjugation of $\pi$ network.

\section{Morphologies of the adsorbents}

The absorption spectra of graphene oxide and few-layer graphene (SKRGO) are shown in Fig. 1. The absorption band at $270 \mathrm{~nm}$ corresponds to the deoxygenation and complete reduction of graphene oxide. The concentration of few-layer graphene and graphene oxide to form a stable dispersed solution may significantly manipulate the absorption bands obtained in UV-Visible spectroscopy. The obtained results were similar to that of the reduction of graphene oxide using L-ascorbic acid (FernándezMerino et al. 2010) and L-cysteine (Chen et al. 2011). The occurrence of red shift has been used as a monitoring tool for the reduction of graphene oxide.

Figure 2 represents the XRD patterns of the graphene oxide and reduced graphene (SKRGO). The diffraction peak of graphene oxide $(002)$ at $2 \theta=10.51^{\circ}$ with $\mathrm{d}$-spacing of $0.84 \mathrm{~nm}$ indicates the formation of oxygencontaining functional groups between the layers. The XRD patterns of SKRGO revealed the disappearance of the (002) reflection peak with a broad peak at $2 \theta=26.5^{\circ}$ (d-spacing $=0.33 \mathrm{~nm}$ ) which is different from that of pristine graphite. This suggests the complete reduction of graphene oxide by phytoextract and formation of fewlayer graphene.

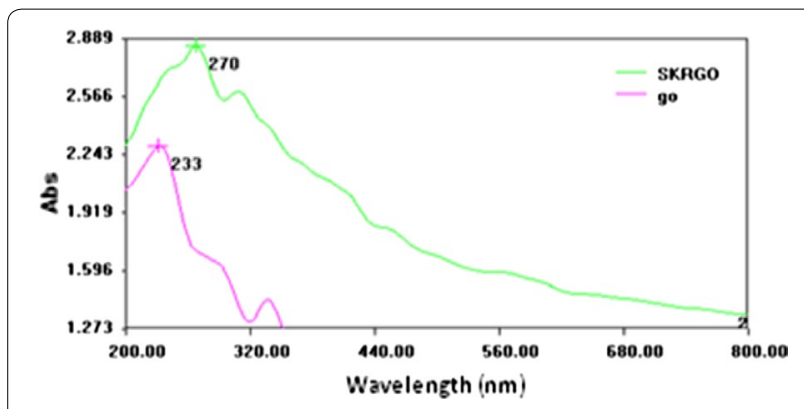

Fig. 1 UV-visible absorption spectra of graphene oxide and fewlayer graphene (SKRGO)

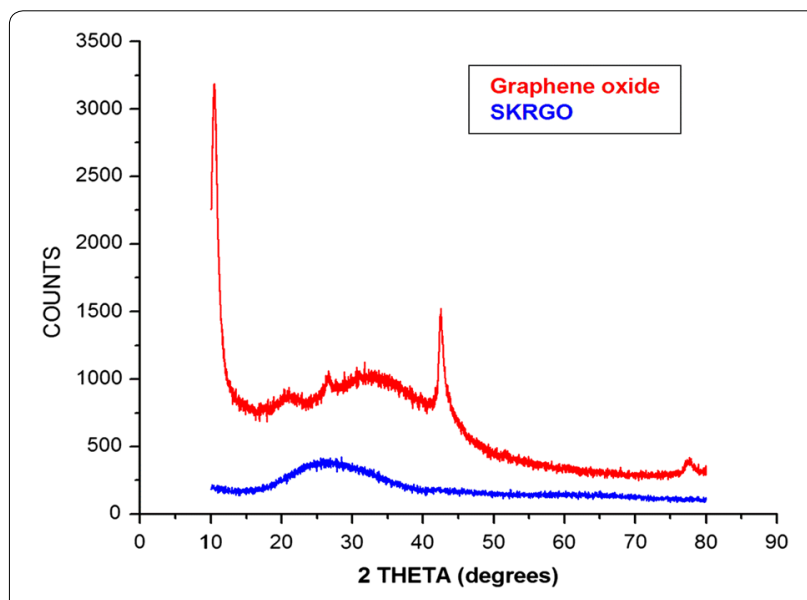

Fig. 2 X-ray diffraction patterns of graphene oxide and SKRGO

The particle size of the synthesized graphene (SKRGO) is $369 \mathrm{~nm}$ (Fig. 3). The zeta potential measurement of reduced graphene oxide is $-48.5 \mathrm{mV}$ indicates the formation of anionic-charged particles (Fig. 4). Graphene possessing positive surface charge absorbs anions, whereas negative surface charge will have the benefits of absorbing cations (Meo 2013). Li et al. (2013) reported that the presence of surface negative charge on graphene materials attracts the positively charged $\mathrm{Cu}^{2+}$. The zeta potential values less than $-30 \mathrm{mv}$ indicates strong repulsive forces. The zeta potential results of biosynthesized graphene (SKRGO) revealed the presence of negative surface charge which can absorb cations, its stability and water insoluble property may find application in the removal of heavy metal ions. Hence, SKRGO can be used as an adsorbent in the treatment of effluents.

The Raman shift of biosynthesized graphene (SKRGO) shows D band at $1359 \mathrm{~cm}^{-1}$ and $G$ band at $1591 \mathrm{~cm}^{-1}$ which reveal the presence of few-layer graphene (Fig. 5). The complete loss of 2D peak $\left(2670 \mathrm{~cm}^{-1}\right)$ accompanied by peak broadening and $20-30 \mathrm{~cm}^{-1}$ shift of G band suggests that the graphene flakes are composed of 5-20 layers (Chabot et al. 2013). The variations in the relative intensities of the G peak and D peak in the Raman spectra of biosynthesized graphene indicate a change in the electronic conjugation state.

The structure of reduced graphene oxide (SKRGO) was further confirmed by X-ray photoelectron spectroscopy (XPS), a surface-sensitive analytical technique useful to determine the chemical environment of atoms. The oxygen content of RGO mostly expressed as carbon to oxygen ratio $(\mathrm{C} / \mathrm{O})$ is a widely accepted criterion for evaluation of the reduction process. XPS spectra show the presence of $\mathrm{C} 1 \mathrm{~s}$ and $\mathrm{O} 1 \mathrm{~s}$ (Fig. 6) which is on par with that of previous literature (Abdolhosseinzadeh 


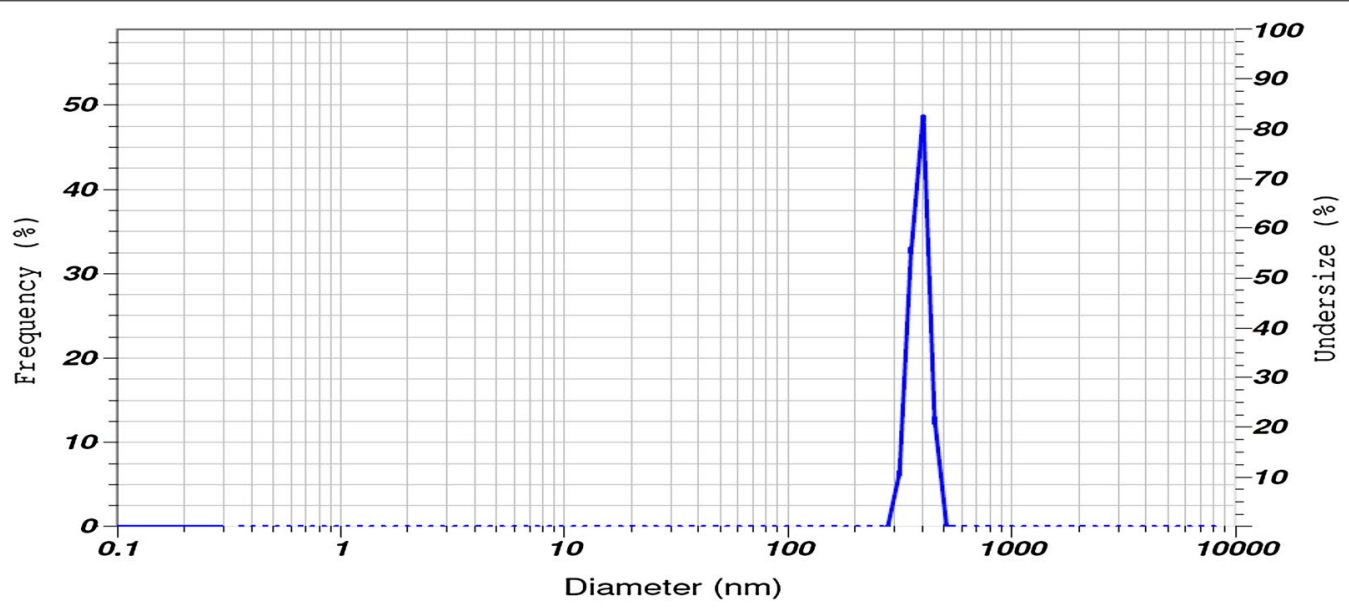

Fig. 3 Particle size distribution of reduced graphene oxide (SKRGO)

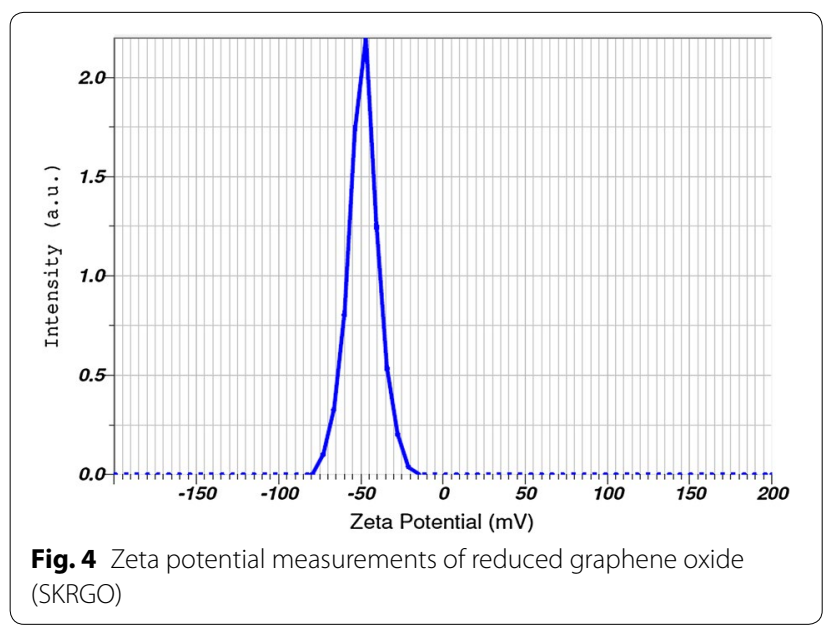

et al. 2015). The C/O ratio in the XPS spectra of SKRGO revealed a successful reduction process (Fig. 6).

The SEM images and its EDAX spectrum of the adsorbent (GAM) before and after treatment with textile effluent are shown in Figs. 7, 8. The formation of fewlayer graphene (SKRGO) was confirmed by SEM images (Fig. 8). The EDAX spectrum clearly showed the presence of silver nanoparticles before and after treatment with textile effluent (Fig. 7). Thus the results revealed that the silver nanoparticles still remained in the graphene and adsorption of other elements onto the adsorbent surface. The EDAX measurements of the synthesized adsorbent (GA) confirms the reduction of graphene oxide using the extract of Amaranthus polygonoides as seen from the significant reduction of oxygen content (20 atom \%)

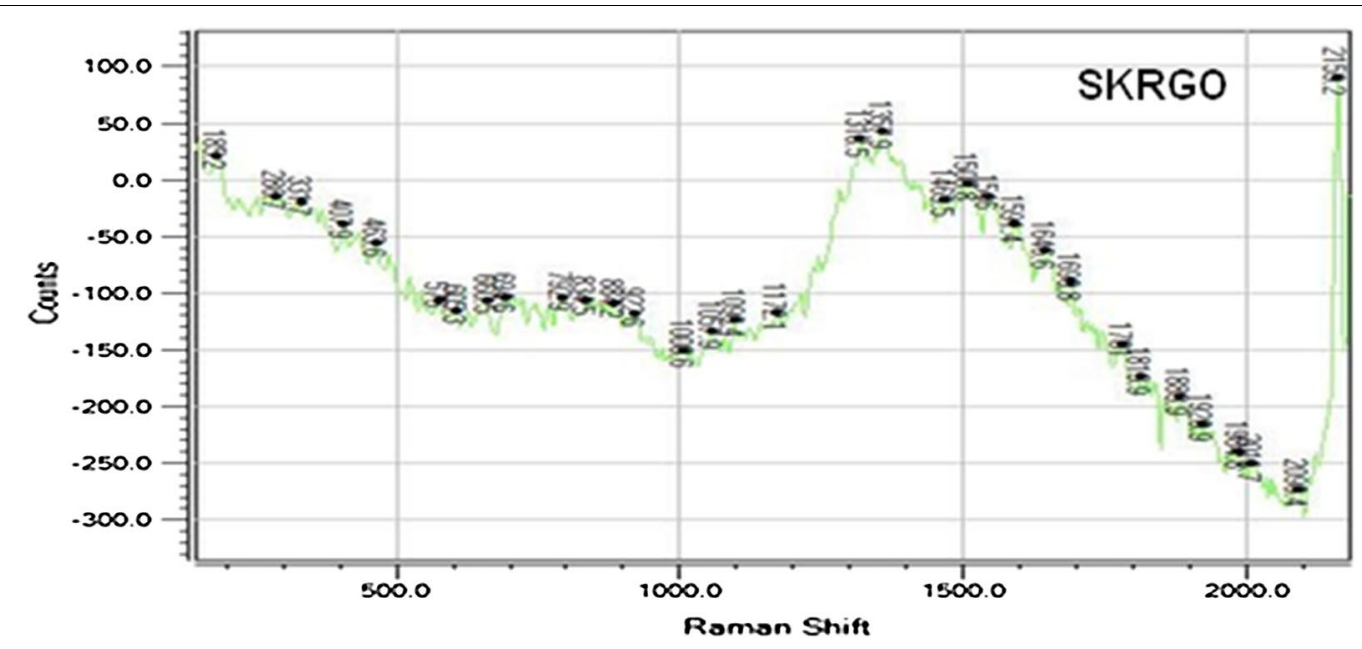

Fig. 5 Raman spectra of synthesized graphene (SKRGO) 


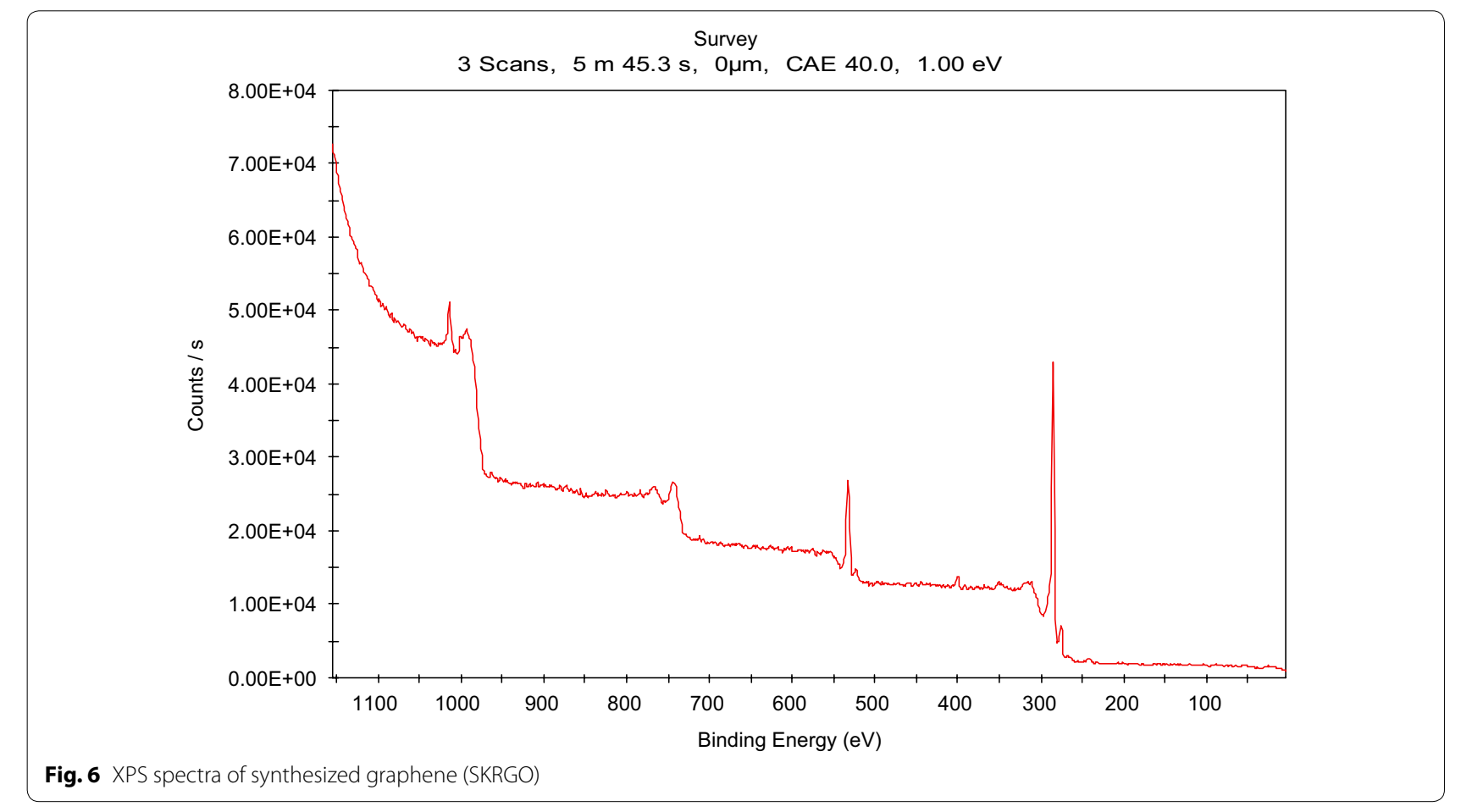

and decreased $\mathrm{C} / \mathrm{O}$ ratio (Fig. 7) compared to that of graphene oxide reported (Firdhouse and Lalitha 2013).

The TEM images of the synthesized graphene (SKRGO) (Figs. 9a, b), silver nanoparticles (Fig. 9c) and SKRGO loaded with silver nanoparticles (GA) (Figs. 9d, $\mathrm{e}, \mathrm{f}$ ) reveal the formation of few-layer graphene using the aqueous extract of $A$. polygonoides. The monodispersed spherical shaped biosynthesized silver nanoparticles using the same plant extract is shown in Fig. 9c. The graphene decorated with silver nanoparticles is clearly depicted in Figs. 9d, e and the monodispersed spherical shaped silver nanoparticles $(10-20 \mathrm{~nm})$ is labelled in Fig. 9f.

\section{Proposed reduction mechanism of GO to graphene}

Betalamic acid is the main constituent of $A$. cruentus, A. blitum, A. dubius and A. tricolour. Betalains a structurally related chromoalkaloid has betalamic acid as the chromophore (Biswas et al. 2013). From the aforesaid reports on plants of genus Amaranthus, it is proposed that the metabolite betalamic acid could be the molecule responsible for the reduction of graphene oxide. The probable mechanism of reduction by betalamic acid is given below (Scheme 1) as evidenced from the presence of alkaloids in $A$. polygonoides extract. The presence of N1s in the XPS spectra (Fig. 6) reveals that the nitrogen in betalamic acid may be accountable for the reduction of graphene oxide to graphene.

\section{Adsorption efficiency of adsorbents}

A preliminary study was conducted to find out the efficacy of the four adsorbents viz. G, GA, GAM, GM and $\mathrm{AC}$ in the treatment of three synthetic effluent samples-textile, tannery and paper mill and its results were discussed. The absorbance of the effluent samples before and after treatment with the four adsorbents is given in Table 1 . The absorbance results reveal that all four adsorbents used for treating textile effluent showed better results compared to that of paper mill and tannery effluents. Initially, rapid adsorption occurs which may be due to the large number of available sites on the adsorbents in the initial stage. As time proceeds, the concentration gradients gradually reduced the deposition or adsorption of salts on the surface sites of GA and GAM, leading to the decrease in the adsorption rate at the later stage. Thus, it decreases the adsorption capability of GA and GAM when treated with other (paper mill and tannery) effluents.

The adsorption efficacy of the adsorbents was calculated from the absorbance values of the effluents obtained before and after treatment with four absorbents with textile, tannery and paper mill effluents (Table 1). The results of percentage adsorption obtained for the four adsorbents show greater efficiency for textile and tannery effluents than paper mill effluent. The percentage adsorption was 98, 92, 94, 84 and $81 \%$ for GAM, GA, AC, G and GM, respectively, when used for treatment with textile effluent 


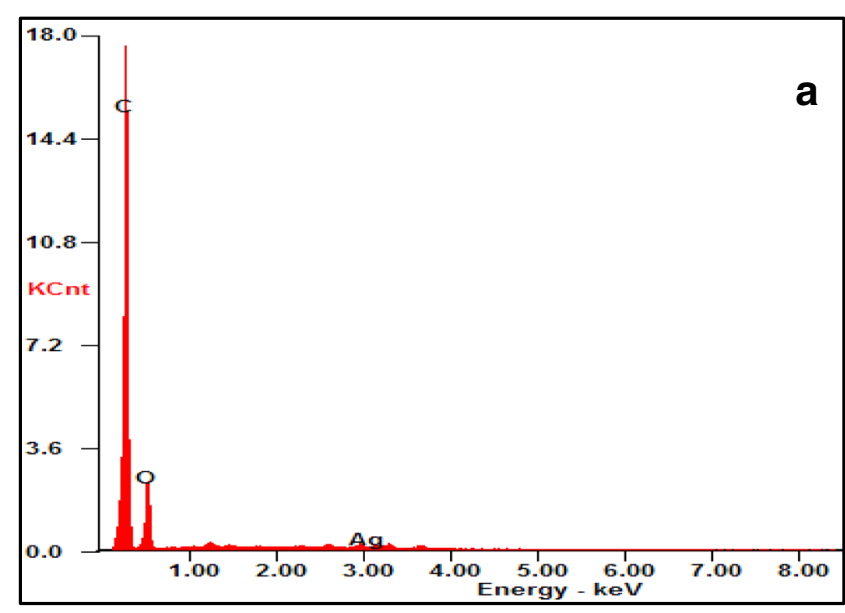

\begin{tabular}{|l|c|c|}
\hline Element & Wt \% & At \% \\
\hline $\boldsymbol{C} \boldsymbol{K}$ & 76.42 & 81.70 \\
\hline $\boldsymbol{O} \boldsymbol{K}$ & 22.67 & 18.19 \\
\hline $\boldsymbol{A g L}$ & 00.91 & 00.11 \\
\hline
\end{tabular}

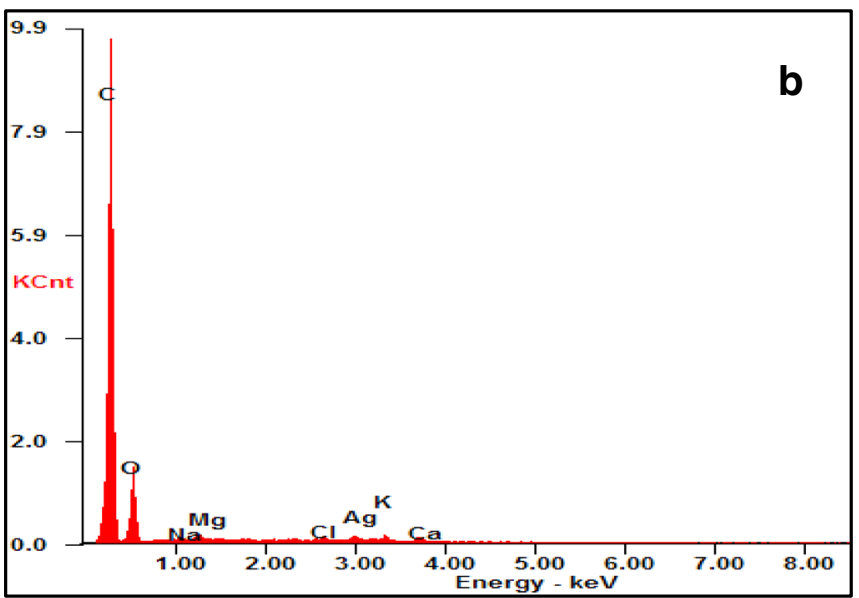

\begin{tabular}{|l|c|c|}
\hline Element & Wt \% & At \% \\
\hline $\boldsymbol{C} \boldsymbol{K}$ & 75.86 & 81.68 \\
\hline $\boldsymbol{O} \boldsymbol{K}$ & 21.86 & 17.67 \\
\hline $\mathbf{N a K}$ & 00.13 & 00.07 \\
\hline $\boldsymbol{M g K}$ & 00.28 & 00.15 \\
\hline $\boldsymbol{C I} \boldsymbol{K}$ & 00.23 & 00.08 \\
\hline $\boldsymbol{A g L}$ & 00.91 & 00.11 \\
\hline $\boldsymbol{K} \boldsymbol{K}$ & 00.37 & 00.12 \\
\hline CaK & 00.32 & 00.10 \\
\hline
\end{tabular}

Fig. 7 EDAX spectrum of GAM before (a) and after treatment (b) with the textile effluent

samples. In the case of treated tannery effluent samples above $50 \%$ percentage adsorption was obtained for all the three adsorbents. Nearly $30 \%$ percentage adsorption potential for all three adsorbents was observed when used for treating paper mill effluent (Table 2).

The results of the percentage adsorption obtained for four different adsorbents (G, GA, GAM, GM and AC) reveals that the GAM possesses good adsorbent efficacy than the other adsorbents. This may be due to the presence of organic moieties in the textile effluent which get adsorbed easily onto the surface of the adsorbents. Hence, the difference in sorption behaviour may be associated with the distributed species under the experimental conditions and also the interaction of the species onto the surface of the selected adsorbents. Hence, textile effluent sample was taken for further studies.

Based on the results of percentage adsorption, textile effluent sample was treated with GAM adsorbent and the physicochemical parameters were analysed for the treated sample.
The control size of AgNPs on the surface of few-layer graphene offers a possible strategy for further improving the adsorption performance of the prepared composite (GA). In addition to this, the coagulation property of $M$. oleifera in GAM enhances the adsorption efficacy than GA. Hence, GAM adsorbents were chosen particularly for the treatment of textile effluent and the quality of water sample collected after treatment of synthetic textile effluent was validated in the laboratory of SITRA (South Indian Textile Research Association), a certified laboratory for testing water quality. Figure 10 is the photograph of columns packed with GAM for treating the synthetic textile effluent. The water collected after treatment with the GAM adsorbent was analysed for water quality parameters according to the standard methods (APHA 2002; Booth (1983)) and the results are given in Table 3. The results are compared with various water quality standards prescribed by Indian Standard Institute (ISI) (Indian Standard 1991). 


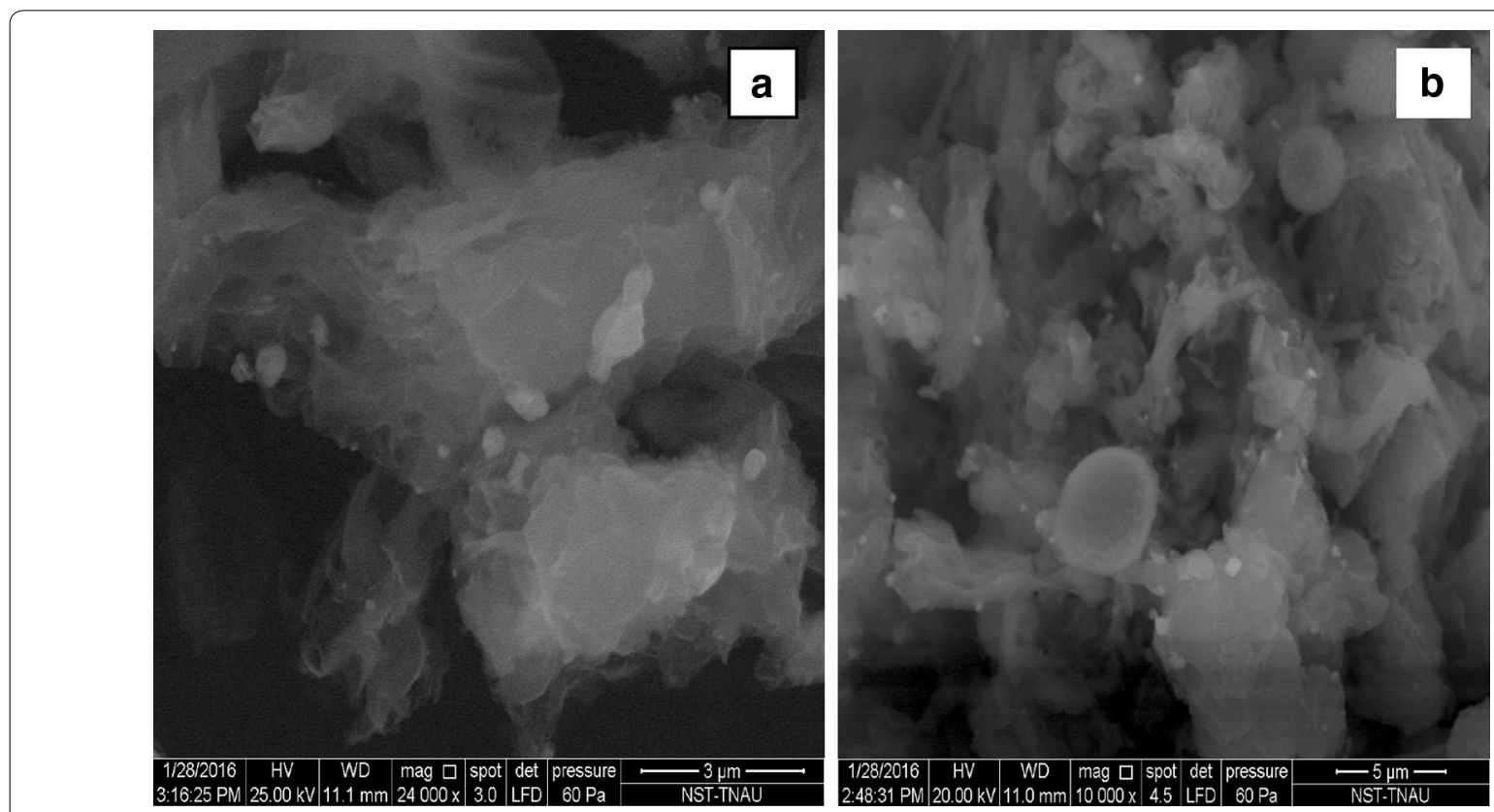

Fig. 8 SEM images of GAM before and after treatment with the textile effluent
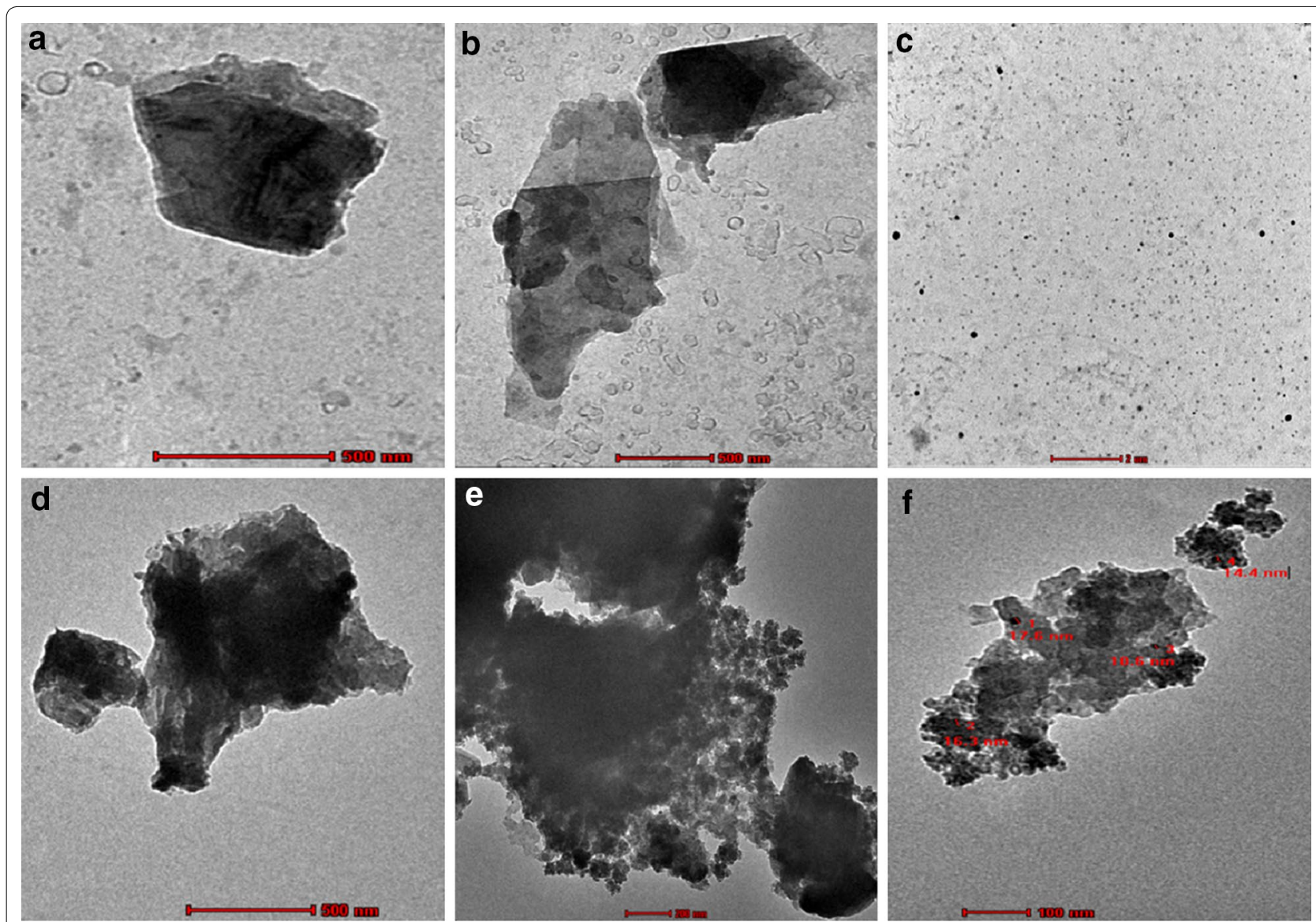

Fig. 9 TEM analysis of synthesized graphene (SKRGO) $(\mathbf{a}, \mathbf{b})$, silver nanoparticles (c) and SKRGO loaded with silver nanoparticles $(G A)(\mathbf{d}, \mathbf{e}, \mathbf{f})$ 
<smiles>CC(C)(C)C1=CC(=CC=O)CC(C(=O)O)N1</smiles>

Betalamic acid

\section{(Amaranthuspolygonoides)}

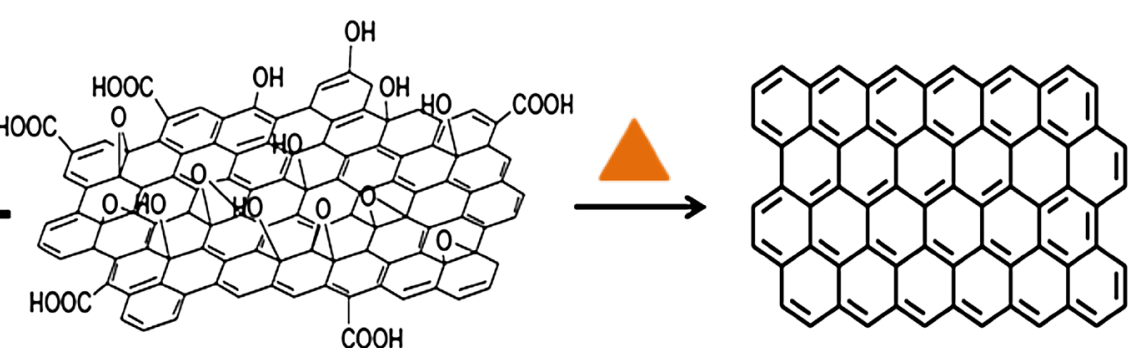

Graphene oxide (GO)

Reduced Graphene oxide (RGO)

Table 1 Comparison of absorbance of synthetic effluent samples before and after treatment with adsorbents

\begin{tabular}{|c|c|c|c|c|c|c|}
\hline \multirow[t]{3}{*}{ Absorbents used in the study } & \multicolumn{6}{|c|}{ Absorbance at $540 \mathrm{~nm}$ obtained before and after treatment with effluents } \\
\hline & \multicolumn{2}{|c|}{ Textile and dyeing } & \multicolumn{2}{|c|}{ Tannery } & \multicolumn{2}{|c|}{ Paper mill } \\
\hline & Before & After & Before & After & Before & After \\
\hline Graphene (G) & 0.81 & 0.13 & 0.91 & 0.32 & 0.78 & 0.66 \\
\hline Graphene + AgNPs (GA) & & 0.06 & & 0.28 & & 0.54 \\
\hline Graphene + AgNPs + M. oleifera (GAM) & & 0.02 & & 0.27 & & 0.51 \\
\hline Activated charcoal (AC) & & 0.05 & & 0.40 & & 0.52 \\
\hline Graphene + M. oleifera (GM) & & 0.15 & & 0.26 & & 0.60 \\
\hline
\end{tabular}

The absorbance of the textile effluent before treatment with adsorbents, analysed by UV-Visible spectroscopy (Fig. 11) reveals two bands at 330 and $560 \mathrm{~nm}$ indicating the presence of chromophoric groups. The effluent after treatment with adsorbent (GA) shows only one band at $560 \mathrm{~nm}$ and the intensity of this band is less compared to the band obtained for textile effluent sample. Lesser absorption bands indicate less UV active chemical components. Obviously the two bands present in the textile effluent sample was found to absent in the sample after treatment with the GAM and AC adsorbents (Fig. 11). Hence, it was observed that graphene loaded with silver nanoparticles and M. oleifera seed powder (GAM) showed better results compared to activated charcoal (AC) and greater efficiency than graphene loaded with silver nanoparticle (GA) adsorbent.

\section{Results of physicochemical characteristics of textile effluent before and after treatment with GA and GAM}

The physicochemical characteristics of textile effluent and the water sample obtained after treatment with GA and GAM adsorbents are given in Table 3. The intensity of the effluent colour decreased to 7 and 17 from 158 after treating the textile effluent with GA and GAM adsorbents, respectively. No characteristic odour was observed for the water samples collected after treatment with GA and GAM adsorbents. The turbidity present in the effluent was found to be less in the treated sample indicating the deposition of organic moieties onto the adsorbents. Due to the adsorption of organic salts the total hardness of the treated textile effluent decreased by $30 \%$ entailing the adsorbent efficacy of GA and GAM.

The BOD and COD values of the textile effluent (1334 and $3625 \mathrm{mg} / \mathrm{L}$, respectively) reduced to 407 and $897 \mathrm{mg} / \mathrm{L}$ respectively, after treating with GA adsorbent. The BOD and COD values decreased to 79 and $274 \mathrm{mg} / \mathrm{L}$, respectively with GAM adsorbent. The chloride content reduced to 550 and $170 \mathrm{mg} / \mathrm{L}$ from $700 \mathrm{mg} / \mathrm{L}$ for the sample treated with GA and GAM adsorbents, respectively. The total dissolved solids also diminished to 2130 and $560 \mathrm{mg} / \mathrm{L}$ from $2270 \mathrm{mg} / \mathrm{L}$ for GA and GAM treated sample revealing the appreciable adsorption potential of GAM. The above results portray the good adsorption potential of GAM. The adsorbent can treat water efficiently by retaining the original properties of normal tap water.

Nanosilver-decorated graphene material owns the adsorption characteristics of AgNPs and the extraordinary properties of graphene, such as a large surface area, and antimicrobial activity of AgNPs and coagulation property of protein present in the seeds of M. oleifera. These results indicate that GAM adsorbent is suitable for the treatment of both industrial wastewater and ground water. The 


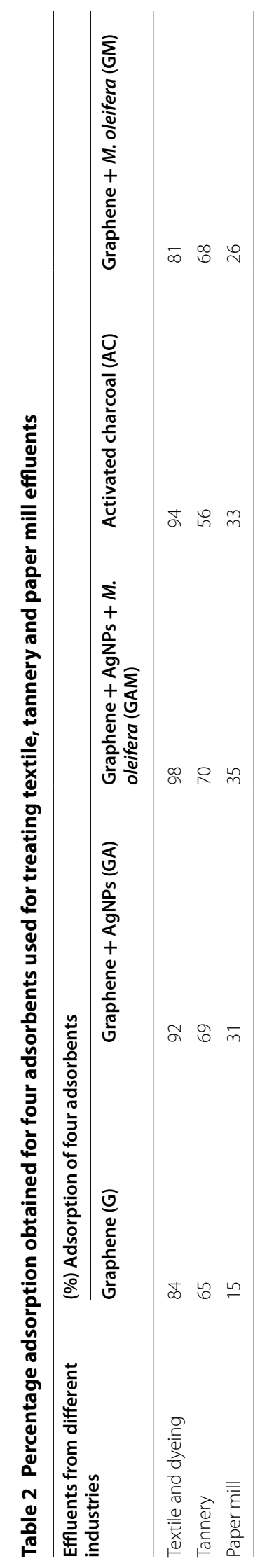




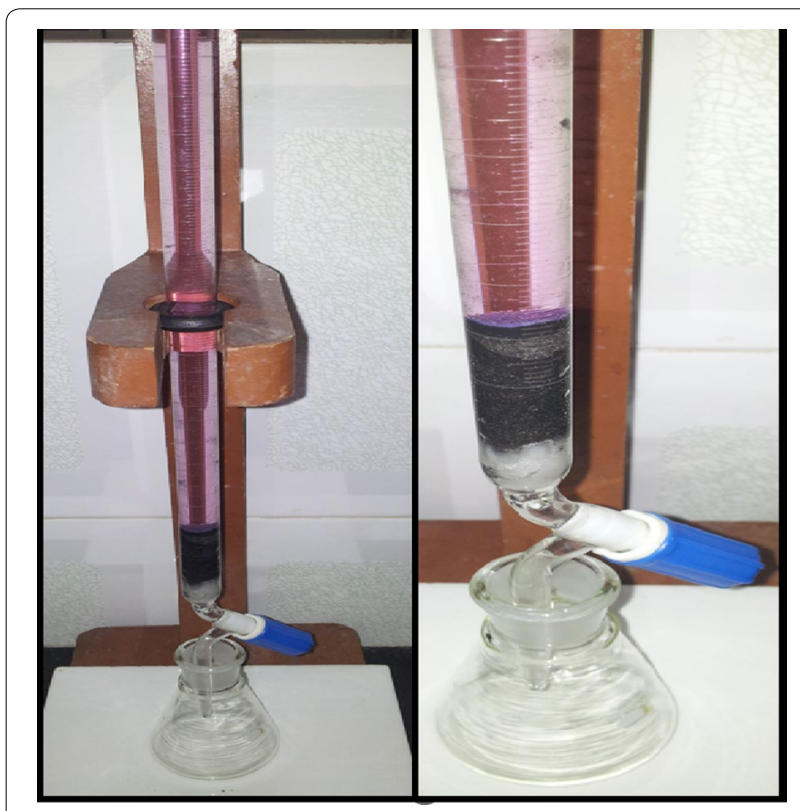

Fig. 10 Photograph of adsorption column containing GAM treated with textile effluent

higher adsorption is due to protonation on the surface of the adsorbent. This may be due to the planar sheet structure and high surface area of graphene may be responsible for stronger protonation of the functional groups present in the effluent on the surface of adsorbent. Similar observation is reported by earlier worker (Yusuf et al. 2015).

The positive charge on the carbon surface is due to the presence of basic surface groups, the excessive protonation of the carbon surface at low $\mathrm{pH}$ values, to graphene layers that act as Lewis bases. These Lewis bases result in the formation of acceptor-donor complexes important for the absorption of many organic compounds. At higher $\mathrm{pH}$ values, the carbon surface has a negative charge due to the ionization of acidic-carbon-oxygen surface groups. The adsorption of metals mainly involves electrostatic interaction between the positively charged metal ionic species present in the solution and the negative sites created by the ionization of the acidic-carbon-oxygen surface groups involving ion-exchange mechanism (Tascón 2012). Active sand supported with sugar-derived graphenic material made through green methods show better adsorption capacity for Rhodamine 6G dye and Chlorpyrifos pesticide (Gupta et al. 2012). The overall adsorption process may be controlled by either one or more steps, including outer diffusion, intra-particle diffusion and adsorption of the adsorbates onto active sites (Rengaraj et al. 2004).

Activated carbon can be produced using either physical or chemical processes $([9,12])$. In the physical process, high temperatures $\left(700-800{ }^{\circ} \mathrm{C}\right)$ are maintained to remove the non-carbon species and to increase the porosity it undergoes an activation process. Compounds like $\mathrm{H}_{3} \mathrm{PO}_{4}$ or $\mathrm{ZnCl}_{2}$ are used in the chemical process. This results in charring and aromatization of the carbon skeleton and creation of the porous structure (Dabrowski et al. 2005). Activated carbon is not efficient for disinfection and nitrate removal (Streat et al. 1995). If these contaminants have low adsorb ability, the powdered form may be more costly and may generate sludge disposal problems (Moreno-Castilla et al. 1995). These shortcomings can be overcome by graphene-modified adsorbents.

Functionalized nano-sized graphene has been used as a drug carrier for in vitro intracellular delivery of anticancer chemotherapy drugs (Sun et al. 2008). It has been found that nanographene with a biocompatible polyethylene glycol (PEG) coating exhibited high passive in vivo tumour uptake and could be used for effective

Table 3 Physicochemical characteristics of effluent before and after treatment with adsorbents GA and GAM

\begin{tabular}{|c|c|c|c|c|}
\hline \multirow[t]{2}{*}{ S. no } & \multirow[t]{2}{*}{ Water quality parameters } & \multicolumn{3}{|l|}{ Textile effluent } \\
\hline & & Before treatment & After treatment with GA & After treatment with GAM \\
\hline 1. & Temperature $\left({ }^{\circ} \mathrm{C}\right)$ & 29.9 & 29.9 & 29.9 \\
\hline 2. & Colour, hazen & 158 & 7 & 17 \\
\hline 3. & Odour & Decaying fruit flavour & No characteristic odour & No characteristic odour \\
\hline 4. & $\mathrm{pH}$ at $27^{\circ} \mathrm{C}$ & 9.10 & 9.25 & 8.19 \\
\hline 5. & Turbidity, NTU & 51 & 3 & 8 \\
\hline 6. & Total alkalinity, as $\mathrm{CaCO}_{3}(\mathrm{mg} / \mathrm{l})$ & 620 & 1220 & 160 \\
\hline 7. & Total hardness, as $\mathrm{CaCO}_{3}(\mathrm{mg} / \mathrm{l})$ & 750 & 550 & 110 \\
\hline 8. & Biochemical oxygen demand, $(\mathrm{mg} / \mathrm{l}), 27^{\circ} \mathrm{C}, 3$ days & 1334 & 407 & 79.5 \\
\hline 9. & Chemical oxygen demand (COD) (mg/l) & 3625 & 897 & 274 \\
\hline 10. & Chlorides, as $\mathrm{Cl}^{-}(\mathrm{mg} / \mathrm{l})$ & 700 & 550 & 170 \\
\hline 11. & Total dissolved solids (mg/l) (evaporation method) & 2270 & 2130 & 560 \\
\hline
\end{tabular}




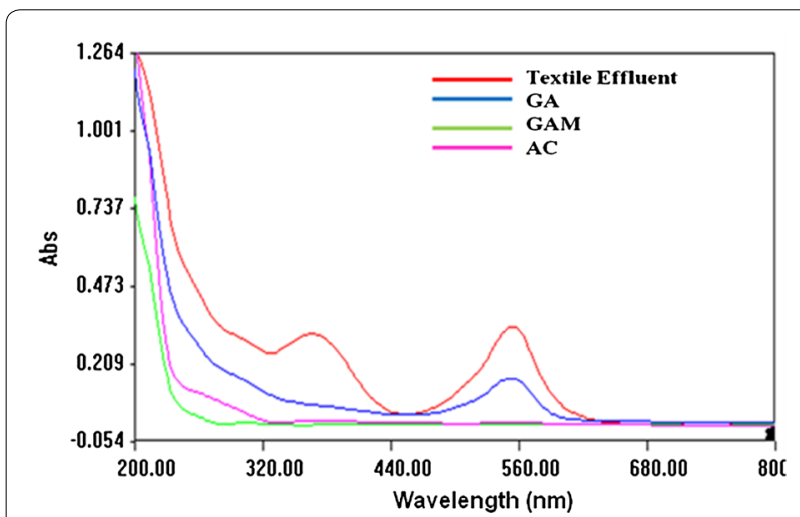

Fig. 11 UV-Visible spectrum of the textile effluent before and after treatment with G, GA, GAM and AC adsorbents. Results of physicochemical characteristics of textile effluent before and after treatment with GA and GAM

photothermal ablation of tumours in a mouse model (Liu et al. 2008). Aromatic anticancer drugs (e.g. SN38 and Doxorubicin) were effectively loaded on the graphene surface via $\pi-\pi$ stacking for intracellular drug delivery (Zhang et al. 2010; Yang et al. 2008). Ultra-high drug loading efficiency was achieved owing to the extremely large surface area of graphene, which has every atom exposed on its surface (Markovic et al. 2010). Hence the nanographene are biocompatible and non-toxic.

Therefore, the adsorbents follow multiple mechanisms during adsorption, including electrostatic attraction and surface complexation, which causes the occurrence of multilayer sorption. For practical applications, further studies such as economic evaluation, continuous flow adsorption and field experiments are warranted. The results of the study reveal GAM to exhibit good adsorption potential. This may be due to the composition of GAM adsorbent which is endorsed by the surface area, antimicrobial and adsorption potential of graphene and silver nanoparticles. Thus the composite prepared in the present work is a very low-cost adsorbent with ease of preparation and also eco-friendly. Hence it is a promising adsorbent in water treatment.

\section{Conclusions}

The bio-reduction of graphene oxide using the aqueous extract of $A$. polygonoides was achieved and confirmed by UV-Visible spectroscopy XRD and XPS analysis. The formation of few layers of graphene with anionic-charged particles was analysed by SEM, TEM and zeta potential analysis, respectively. The enhancement of the adsorption potential of graphene was done by the fabrication of biosynthesized silver nanoparticles. The post adsorption analysis of the adsorbents (G, GA, GAM, GM and AC) evidently revealed that the graphene loaded with silver nanoparticles and seed powder of $M$. oleifera composite (GAM) showed superior results compared to conventional adsorbents. This may be due to the composition of GAM adsorbent which is endorsed by the surface area, antimicrobial and adsorption potential of graphene and silver nanoparticles, in addition to the coagulation property of protein present in the seeds of M. oleifera. Thus the composite prepared in the present work is a very lowcost adsorbent with ease of preparation, eco-friendly and is a promising adsorbent in water treatment.

\section{Authors' contributions}

FMJ carried out the preparation and characterization of the adsorbents and adsorption experiments. LP designed the whole study and both prepared the manuscript. Both authors read and approved the final manuscript.

\section{Acknowledgements}

The authors sincerely thank the Avinashilingam Institute for Home Science and Higher Education for Women University, Coimbatore, Tamil Nadu, for providing research facilities; Department of Physics, of our University for recording XRD and Tamil Nadu Agricultural University, Coimbatore for recording SEM and SITRA, Coimbatore for their help rendered in the water quality analysis.

\section{Competing interests}

The authors declare that they have no competing interests.

Received: 17 November 2015 Accepted: 27 February 2016

Published online: 10 March 2016

\section{References}

Abdolhosseinzadeh S, Asgharzadeh H, Kim HS (2015) Fast and fully-scalable synthesis of reduced graphene oxide. Sci Rep 5:1-7. doi:10.1038/ srep 10160

Acharya J, Sahu JN, Mohanty CR, Meikap BC (2009) Removal of lead(II) from wastewater by activated carbon developed from Tamarind wood by zinc chloride activation. Chem Eng J 149:249-262

Aglietto I (2010) Advanced photocatalytic oxidation with graphene for waste water treatment. ENT magazine 33-36

Ahmedna M, Marshall WE, Husseiny AA, Rao RM, Goktep I (2004) The use of nutshell carbons in drinking water filters for removal of trace metals. Water Res 38:1062-1068

Alam MZ, Muyibi SA, Mansor MF, Wahid R (2007) Activated carbons derived from oil palm empty-fruit bunches: application to environmental problems. J Environ Sci 19:103-108

Ankamwar B, Surti F (2012) Water Soluble Graphene Synthesis. Chem Sci Trans 1(3):500-507

APHA (2002) Standard methods for the examination of water and wastewater, Washington, DC: American Public Health Association, 20th edition, Method 2340-c

Asasian N, Kaghazchi T, Soleimani M (2012) Elimination of mercury by adsorption onto activated carbon prepared from the biomass material. J Ind Eng Chem 18:283-289

Ash B, Satapathy D, Mukherjee PS, Nanda B, Gumaste JL, Mishra BK (2006) Characterization and application of activated carbon prepared from waste coir pith. J Sci Ind Res 65:1008-1012

Biswas M, Dey S, Sen R (2013) Betalains from Amaranthus tricolor L. J Pharmacogn Phytochem 1:87-95

Booth RL (1983) Methods for chemical analysis of water and wastes, EPA600/4-79-020, USEPA, method 130.2

Catalano L, Franco I, De Nobili M, Leita L (1999) Polyphenols in olive mill waste waters and their depuration plant effluents: a comparison of the FolinCiocalteau and HPLC methods. Agrochimica 43:193-205

Chabot V, Kim B, Sloper B, Tzoganakis C, Yu A (2013) High yield production and purification of few layer graphene by Gum Arabic assisted physical sonication. Sci Rep. doi:10.1038/srep01378 
Chen D, Li L, Guo L (2011) An environment-friendly preparation of reduced graphene oxide nanosheets via amino acid. Nanotechnology 22(32):325601

Cobb A, Warms M, Maurer EP, Chiesa S (2012) Low-Tech coconut shell activated charcoal production. Int J Serv Learn Eng 7(1):93-104

Cohen-Tanugi D, Grossman JC (2012) Water Desalination across Nanoporous Graphene. Nano Lett 12:3602-3608

Dabrowski A, Podkoscielny P, Hubicki Z, Barczak M (2005) Adsorption of phenolic compounds by activated carbon-a critical review. Chemosphere 58:1049-1070

Dalen MB, Pam JS, Izang A, Ekele R (2009) Synergy between Moringa oleifera seed powder and alum in the purification of domestic water. Sci World J 4(4):6-11

Egborge ABM (1991) Industrialization and heavy metal pollution in Warri River., Inaugural lecture seriesUniversity of Benin Press, Benin 32

Eilert U, Wolters B, Nahrstedt A (1981) The antibiotic principle of using Moringa oleifera and Moringa stenopetalla. Planta Med 42:55-61

Emongor V, Kealotswe E, Koorapetse I, Sankwasa S, Keikanetswe S (2005) Pollution indicators in Gaborone Industrial effluent. J Appl Sci 5:147-150

Evans AEV, Hanjra MA, Jiang Y, Qadir M, Drechsel P (2012) Water pollution in Asia: The urgent need for prevention and monitoring, http://www. globalwaterforum.org/2012/06/09/water-pollution-in-asia-the..

Federal Environmental Protection Agency (FEPA) (1991) Water Quality, Federal Water Standards, Guidelines and Standard for Environmental Pollution Control in Nigeria, National Environmental Standards - Part 2 and 3. Government Press, Lagos, p 238

Fernández-Merino MJ, Guardia L, Paredes JL et al (2010) Vitamin-C as an innocuous and safe reductant for the preparation of graphene suspensions from graphite oxide. J Phys Chem C 114:6426-6432

Firdhouse MJ, Lalitha P (2013) Eco-friendly synthesis of graphene using the aqueous extract of Amaranthus dubius. Carbon Sci Technol 5(2):253-259

Firdhouse MJ, Lalitha P (2014) Phyto-reduction of graphene oxide using the aqueous extract of Eichhornia crassipes (Mart.) Solms. Int Nano Lett 4:103-108

Gerçel Ö, Özcan A, Özcan AS, Gerçel HF (2007) Preparation of activated carbon from a renewable bio-plant of Euphorbia rigida. App Surf Sci 253:4843-4852

Gupta SK (2011) Modern Hydrology and sustainable water development. Wiley, Hoboken

Gupta Sreeprasad TS, Maliyekkal SM, Das SK, Pradeep T (2012) Graphene from sugar and its application in water purification. ACS Appl Mater Interfaces 4:4156-4163

Huang J, Tan XD, Yang YJ, Zheng J, Wang YT (2011) Preparation and characterization of activated carbon from Pyrolusite-Added herb residues. Adv Sci Lett 4:3512-3516

Indian Standard 10500 (1991) Indian standard drinking water-specification. Bureau of Indian Standards, New Delhi

Jain SK, Purkait MK, De S, Bhattacharya PK (2006) Treatment of leather plant effluent by membrane separation processes. Separ Sci Technol 41:3329-3348

Kadirvelu K, Senthilkumar P, Thamaraiselvi K, Subburam V (2002) Activated carbon prepared from biomass as adsorbent: elimination of $\mathrm{Ni}(\mathrm{II})$ from aqueous solution. Bioresour Technol 81(1):87-90

Khurshid S, Abdul B, Zaheeruddin A, Usman SM (1998) Effect of waste disposal on water quality in parts of Cochin, Kerala. Indian J Environ Health 40(1):45-50

Koutcheiko S, Monreal CM, Kodama H, McCracken T, Kotlyar L (2007) Preparation and characterization of activated carbon derived from the thermo-chemical conversion of chicken manure. Bioresour Technol 98(13):2459-2464

Kumar A, Prasad B, Mishra IM (2008) Optimization of process parameters for acrylonitrile removal by a low-cost adsorbent using Box-Behnken design. J Hazard Mater 150:174-182

Lee J, Chae HR, Won YJ, Lee K, Lee CH, Lee H, Kim I, Lee JM (2013) Graphene oxide nanoplatelets composite membrane with hydrophilic and antifouling properties for waste-water treatment. J Membrane Sci 448:223-230

Li M, Liu C, Cao H, Zhang Y (2013) Surface charge research of graphene oxide, chemically reduced graphene oxide and thermally exfoliated graphene oxide. Adv Mater Res 716:127-131
Lia K, Lia Y, Hub H (2011) Adsorption characteristics of lead on cotton-stalkderived activated carbon fibre by steam activation. Desalin Water Treat 30:1-9

Liu Z, Robinson JT, Sun XM, Dai HJ (2008) PEGylated nanographene oxide for delivery of water-insoluble cancer drugs. J Am Chem Soc 130:10876-10877

Lokhande RS, Singare PU, Pimple DS (2011) Toxicity study of heavy metals pollutants in waste water effluent samples collected from Taloja Industrial Estate of Mumbai India. Resour Environ 1(1):13-19

Ma J, Wang X, Liu Y, Wu T, LiuY Guo Y, Li R, Sun X, Wu F, Li C, Gao J (2013) Reduction of graphene oxide with L-lysine to prepare reduced graphene oxide stabilized with polysaccharide polyelectrolyte. J Mater Chem A 1:2192-2201

Madsen M, Schlundt J, Omer EF (1987) Effect of water coagulation by seeds of M. oleifera on bacterial concentration. J Trop Med Hyg 1:90-109

Mahimairaja S, Shenbagavalli S, Naidu R (2011) Remediation of Chromiumcontaminated soil due to tannery waste disposal: Potential for phyto- and bioremediation. Pedologist 175-181

Markovic ZM, Harhaji-Trajkovic LM, Todorovic-Markovic BM et al (2010) In vitro comparison of the photothermal anticancer activity of graphene nanoparticles and carbon nanotubes. Biomaterials 32:1121-1129

Meo M (2013) Proceedings of 9th International Conference on Composite Science and Technology Composite Science and Technology: 2020-Scientific and Technical Challenges. Lancaster : DEStech Publication, p. 1053

Moreno-Castilla C, Rivera-Utrilla J, Lopez-Ramon MV, Carrasco-Marin F (1995) Adsorption of some substituted phenols on activated carbons from a bituminous coal. Carbon 33:845-851

Moyo M, Chikazaza L (2013) Bioremediation of Lead(II) from polluted wastewaters employing sulphuric acid treated maize tassel biomass. Am J Anal Chem 4:689-695

Murayama Y, Kobayashi T, Adachi S (2010) Properties of extracts from soy sauce cake using subcritical water treatment. Japan J Food Eng 11(1):67-71

Nagashanmugam KB, Srinivasan K (2011) Hexavalent chromium removal by gingelly oil cake carbon activated with zinc chloride. Indian J Chem Technol 18:391-402

Nevondo TS, Cloete TE (1999) Bacterial and chemical quality of water in the Dertig village settlement. Water SA 25(2):215-220

Olayemi AB, Alabi RO (1994) Studies on traditional water purification using $M$. Oleifera seeds. African Study Monographs 15(3):135-142

Pachpande BG, Ingle ST (2004) Recovery of the Chromium by chemical precipitation from tannery effluent. Orient J Chem 20(1):117-123

Prabha S, Selvapathy P (1997) Heavy metal pollution in Indian Rivers. Indian J Environ Prot 17(6):641-649

Prasad A, Rao KVB (2011) Physico chemical analysis of textile effluent and decolorization of textile azo dye by Bacillus Endophyticus strain VITABR13. The IIOAB J 2(2):55-62

Qian Q, Machida M, Tatsumoto H (2007) Preparation of activated carbons from cattle-manure compost by zinc chloride Activation. Bioresour Technol 98:353-360

Rajamanickam R, Nagan S (2010) Performance study of common effluent treatment plants of textile dyeing units in Karur, Tamil Nadu (India). Environ Res Develop 5(3):623-630

Rajaram T, Das A (2008) Water pollution by industrial effluents in India: discharge scenarios and case for participatory ecosystem specific local regulation. Futures 40(1):56-69

Ramakrishnan K, Namasivayam C (2009) Development and characteristics of activated carbons from Jatropha husk, an agro industrial solid waste, by chemical activation methods. J Environ Eng Manage 19(3):173-178

Ramesh Babu B, Parande AK, Raghu S, Prem Kumar T (2007) Cotton Textile Processing: waste generation and effluent treatment. J Cotton Sci 11:141-153

Ranganathan K, Karunagaran K, Sharma DC (2006) Recycling of wastewaters of textile deing industries using advanced treatment technology and cost analysis_Case studies. doi:10.1016/j.resconrec.2006.06.004

Rengaraj S, Kim Y, Joo CK, Yi J (2004) Removal of copper from aqueous solution by aminated and protonated mesoporous aluminas: kinetics and equilibrium. J Colloid Interface Sci 273:14-21

Renugadevi N, Sangeetha R, Lalitha P (2011) Kinetics of the adsorption of methylene blue from an industrial dyeing effluent onto activated 
carbon prepared from the fruits of Mimusops Elengi. Arch Appl Sci Res 3(3):492-498

Rodell M, Velicogna I, Famiglietti JS (2009) Satellite-based estimates of groundwater depletion in India. Nature 460:999-1002

Roloff A, Weisgerber H, Lang U, Stimm B (2009) Moringa oleifera LAM., 1785, Enzyklopädie der Holzgewächse. Handbuch und Atlas der Dendrologie. WILEY-VCH Verlag GmbH and Co KGaA, Weinheim

Sankar MU, Aigal S, Maliyekkal SM, Chaudhary A, Kumar AA, Chaudhari K, Pradeep T (2013) Biopolymer-reinforced synthetic granular nanocomposites for affordable point-of-use water purification. Proc Natl Acad Sci USA 110(21):8459-8464

Sapana MM, Sonal CG, Raut PD (2012) Use of Moringa Oleifera (Drumstick) seed as natural absorbent and an antimicrobial agent for ground water treatment. Res J Recent Sci 1(3):31-40

Selvam K, Priya MS (2012) Biological treatment of Azo dyes and textile industry effluent by newly isolated White rot fungi Schizophyllum commune and Lenzites eximia. Int J Environ Sci 2(4):1926-1935

Selvam K, Priya MS, Yamuna M (2012) Decolourization of azo dyes and dye industry effluents by lignin degrading fungus Trametes versicolor. Int J Pharm Biol Sci Arch 3(3):666-672

Sharma N, Chatterjee S, Bhatnagar P (2013) Assessment of physicochemical properties of textile wastewaters and screening of bacterial strains for dye decolourisation. Univers J Environ Res Technol 3(3):345-355

Sindhu M, Begum K, Sugashini S (2012) A comparative study of surface modification in carbonized rice husk by acid treatment. Desalin Water Treat 45:170-176

Singare PU, Lokhande RS, Pathak PP (2010) Study on physico-chemical properties and heavy metal content of the soil samples from Thane Creek of Maharashtra, India. Interdisciplinary Environ Rev 11(1):38-56

Singh KP, Malik A, Sinha S (2005) Water quality assessment and apportionment of pollution sources of Gomti river (India) using multivariate statistical techniques-a case study. Anal Chimi Acta 538(1-2):355-374

Singh RK, Vats S, Tyagi P (2011) Industrial wastewater treatment by biological activated carbon-A Review. Res J Pharm Biol Chem Sci 2(4):1053-1058

Singleton VL, Orthofer R, Lamuela-Raventós RM (1999) Analysis of total phenols and other oxidation substrates and antioxidants by means of Folin-ciocalteu reagent. Method Enzymol 299:152-178

Sivakumar V, Asaithambi M, Jayakumar N, Sivakumar P (2010) Assessment of the contamination from the tanneries \& dyeing industries on to Kalingarayan Canal of Tamil Nadu. Int J Chem Tech Res 2(2):774-779

Sotheeswaran S, Nand V, Matakite M, Kanayathu K (2011) Moringa oleifera and other local seeds in water purification in developing countries. Res J Chem Environ 15(2):135-138

Streat M, Patrick JW, Camporro Perez MJ (1995) Sorption of phenol and para-chlorophenol from water using conventional and novel activated carbons. Water Res 29:467-472
Sugumaran P, Priya Susan V, Ravichandran P, Seshadri S (2012) Production and characterization of activated carbon from banana empty fruit bunch and Delonix regia fruit pod. J Sustainable Energy Environ 3:125-132

Sun XM, Liu Z, Welsher K et al (2008) Nano-graphene oxide for cellular imaging and drug delivery. Nano Res 1:203-212

Suriyanarayanan S, Mailappa AS, Jayakumar D, Nanthakumar K, Karthikeyan K, Balasubramanian S (2010) Studies on the characterization and possibilities of reutilization of solid wastes from a waste paper based paper industry. Global J Environ Res 4(1):18-22

Tascón J (2012) Novel Carbon Adsorbents. ISBN:9780080977447 Elsevier. pp. 250-260

Uddin MA, Shinozaki Y, Furusawa N, Yamada T, Yamaji Y, Sasaoka E (2007) Preparation of activated carbon from asphalt and heavy oil fly ash and coal fly ash by pyrolysis. J Anal Appl Pyrolysis 78:337-342

Varma S, Sarode D, Wakale S, Bhanvase BA, Deosarkar MP (2013) Removal of Nickel from waste water using graphene nanocomposite. Int J Chem Physical Sci 2:132-139

Vinodkumar V, Chopra AK, Chauhan RK (2012) Effects of textile effluents disposal on water quality of Sub Canal of Upper Ganga Canal at Haridwar (Uttarakhand), India. J Chem Pharm Res 4(9):4206-4211

Vorosmarty CJ, McIntyre PB, Gessner MO, Dudgeon D, Prusevich A, Green P, Glidden S, Bunn SE, Sullivan CA, Liermann CR, Davies PM (2010) Global threats to human water security and river biodiversity. Nature 30:467-555

WHO (2004) Report on Water, Sanitation and Hygiene Links to Health. WHO, Geneva

Wu QF, Zhang S (2012) A clean process for activator recovery during activated carbon production from waste biomass. Fuel 94:426-432

Yang XY, Zhang XY, Liu ZF, Ma YF, Huang Y, Chen Y (2008) High-efficiency loading and controlled release of doxorubicin hydrochloride on graphene oxide. J Phys Chem C 112:17554-17558

Yusuf M, Elfghi FM, Zaidi SA, Abdullaha EC, Khan MA (2015) Applications of graphene and its derivatives as an adsorbent for heavy metal and dye removal: a systematic and comprehensive overview. RSC Adv 5:50392-50420

Zaini MAA, Amano Y, Machida M (2010) Adsorption of heavy metals onto activated carbons derived from polyacrylonitrile fiber. J Hazard Mater 180:552-560

Zhang LM, Xia JG, Zhao QH, Liu LW, Zhang ZJ (2010) Functional graphene oxide as a nanocarrier for controlled loading and targeted delivery of mixed anticancer drugs. Small 6:537-544

Zouboulis Al, Matis KA (1997) Removal of metal ions from dilute solutions by sorptive flotation. Crit Rev Environ Sci Technol 27:195-235

\section{Submit your manuscript to a SpringerOpen ${ }^{\odot}$ journal and benefit from:}

- Convenient online submission

- Rigorous peer review

- Immediate publication on acceptance

- Open access: articles freely available online

- High visibility within the field

- Retaining the copyright to your article

Submit your next manuscript at $>$ springeropen.com 